\title{
Development the renewable energy sector of the Kyrgyz Republic
}

\author{
T. S. Kalybekovich* and O. A. Djumabekovich
}

Kyrgyz State Technical University (KSTU) named after I. Razzakov, Kyrgyz Republic, Bishkek city, Prospect Mira 66, KSTU, 720044

Received 24 July 2012; Accepted 21 December 2012

\begin{abstract}
This article discusses on use of alternative energy sources in Kyrgyz Republic and the ways of solving problems on its development.
\end{abstract}

Keywords: Renewable Energy sources (RES), solar, wind, biogas, geothermal development

\section{Introduction}

The livelihood of roughly 22 million people in Central Asia depends on water. 1.5billion dollars get lose every year South-Eastern Central Asia because of bad water. The Kyrgyz Republic is the "water powers". So far only $10 \%$ of hydropower electricity is exploited in Kyrgyzstan.

The Kyrgyz Republic is a country that is highly dependent on hydroelectric resources for meeting its conventional energy needs. Of the total installed capacity of $3400 \mathrm{MW}$, hydroelectric capacity accounts for about $80 \%$ and the remaining is Combined Heat and Power (CHP) capacity of about $700 \mathrm{MW}$ (Bishkek and Osh CHP plants).

However, in actual production, the dependence on hydroelectricity is almost $90 \%$ since the operate capacity of the CHPs are down to less than $200 \mathrm{MW}$. In addition, the Naryn hydroelectric cascade accounts for $90 \%$ of the hydroelectric capacity, with large Toktogyl reservoir-with a storage capacity of 19 billion cubic meters being the main reservoir that enables the regulated operation of the cascade. In short, the water level in the Toktogul reservoir is the crucial determinant of the energy availability in the country. With other words, in 2007/08 there is was shortage of energy in winter time for 400-500 MW. In this case the our government was applying to the World Bank for the energy emergency assistance.

These things made up for us thinking about the development of renewable energy sector in the republic. On the reports of Ministry of Energy in the energy balance the usage of the renewable energy consist only $0.017 \%$.

Currently, there are domestic developments that use solar thermal, biomass and small streams. During the Soviet time, i.e. 1996 the project "Sun" has been launched production of solar thermal panels for heating needs in food and water in rural areas, but due to insufficient of financing sometimes later operation of the plant was stopped.

In 20 March of 2006 launched a Government Decision of

*E-mail address: Sagun2004@mail.ru

ISSN: 1791-2377 @ 2012 Kavala Institute of Technology. All rights reserved.
"On a phased transfer of cultural and recreational facilities of the Issyk-Kul region to use solar energy." But these initiatives was not fulfilled and the stayed in papers due to absent of financing from the government. Now time we have about 50 biogas installations in totally in Kyrgyzstan. This biogas installations was installed to some rich farmers where have the sufficient quantity of cows and for those which has the own milk processing factories. The most of biogas installations was implemented by helping of JICA project in Kyrgyzstan.

In spite of educated and trained in four universities of Kyrgyz Republic the renewable energy sources (RES) development specialists is weak due to absent of practically and theoretically basis. For that also leading that the in Kyrgyz Republic has not sufficiently professionals and scientists in the education system of RES. One of restricting factors it's the absent of possessing foreign languages our specialists (English) and the international collaborations with $\mathrm{EU}$ and other advanced countries on doing $\mathrm{PhD}$, and pilot demonstrated projects in area of development of Renewable energy in Kyrgyz Republic.

But the market for today in Kyrgyzstan dictated to development of Renewable energy sources, as solar, biogas, wind its hybridizations, especially for those regions and farmers, which is situated far from central electricity supply. Most advanced business class, rich farmers, hotel and sanatoriums owners doing business in beautiful places of valleys in Kyrgyzstan, really need self-supporting energy systems by using of RES.

In Kyrgyz Republic the priority should be given for solar energy. The solar radiation for producing the electricity will be use efficiently in private houses throughout the year in the condition of Kyrgyz Republic. During winter time the PV should be combine with other sources of energy like wind, biogas, geothermal during installation in houses or hotels. But the implementation of this idea has not been demonstrated still with any pilot project, to be shown for whole population about the efficiency of using cheap Solar Energy. In the south of Kyrgyz Republic in Osh, Batken and Jalalabad oblasts should be develop using the solar energy technology. 
By using of the energy of waste animal biomass with biogas installation may supply about $30 \%$ needs of the rural population with biogas. (Note: Kyrgyz Republic has 5 million population, about 1 million have migrated to other countries, the total Kyrgyz nation is about 3 million from this $65 \%$ are concentrated and living in rural mountain places). The using of biogas installation also may support us in developing the agriculture, by supplying us with pure bioorganic fertilizer. That can use for improving the quality of wheat (for improving the gluten of wheat), which can be use for making bread in large scale, instead of buying wheat from another countries like Kazakhstan and Russia. In Naryn region we rare more agricultural animals in the hands of population, in this area implementing the biogas technology is very useful.

In Issykkyl region have more than 100 tourism sanatoriums, where we should use the Solar Energy to produce electricity and to get hot water independently. In the coastal of the Issykkyl region we have more of geothermal sources which can be used also to heat and to get hot water throughout of the year. In Issykkyl region sanatoriums are near to the geothermal sources which are mostly used for medicinal purpose, but it should also be use for heating during winter period and to get hot water throughout the year. By our estimation it can be reduce $40 \%$ electric energy cost of each in above mentioned sanatoriums. Approximately every hotel owners or guesthouses, are paying about 1 million som per year for using the hot water, $(47$ som of Kyrgyz currency $=1 \$)$. Hybridization with PV the geothermal sources in the coastal of sanatoriums region, will were giving a big energy safety for our country. But this potentials also is not being use due to the absent of knowledge or technologies. The energy of wind also has big potentials but the production of appropriate wind installation is not yet installed in the republic.

Our studies have shown that the potential of renewable energy sources in Kyrgyzstan can replace up to $50.7 \%$ of the demand for fuel and energy resources consumed today the republic. In reality, the resources available at the present level of technology and technology make for Kyrgyz Republic of 840.2 million tons of fixed fuel per year [1].

But in spite of all these restricting factors, in Kyrgyz Republic has some experience on the use of solar thermal installations. In previous years (1993-96) it was established more than 30 thousand $\mathrm{m} 2$ of solar collectors in rest homes, sanatoriums, resorts and other facilities in the country.

The use of solar thermal plants (Fig. 1) can not only save money for the purchase of conventional fuels, but also to improve living conditions, making it possible to get hot water for domestic use.

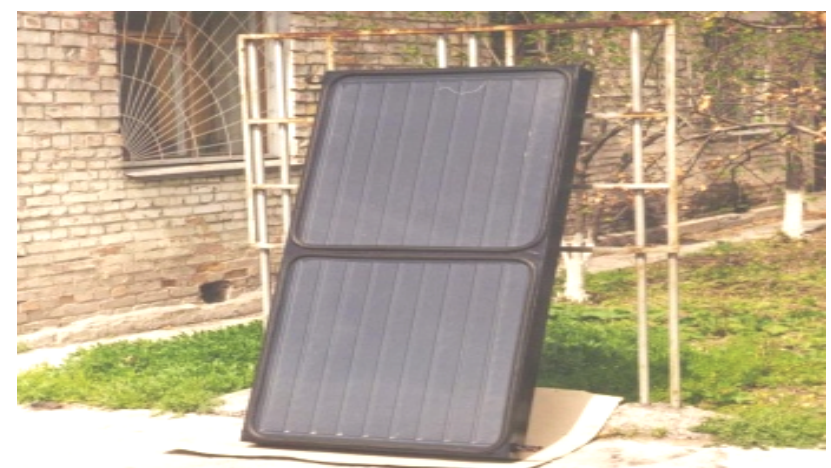

Fig 1. Industry thermal plant sample
In the future, to provide electrical energy, it also seems very promising application of stand-alone photovoltaic solar energy converters, which are shown in Figure 2. But for this we need the knowledge in practical and theoretical plan, which are shown in Figure 2.

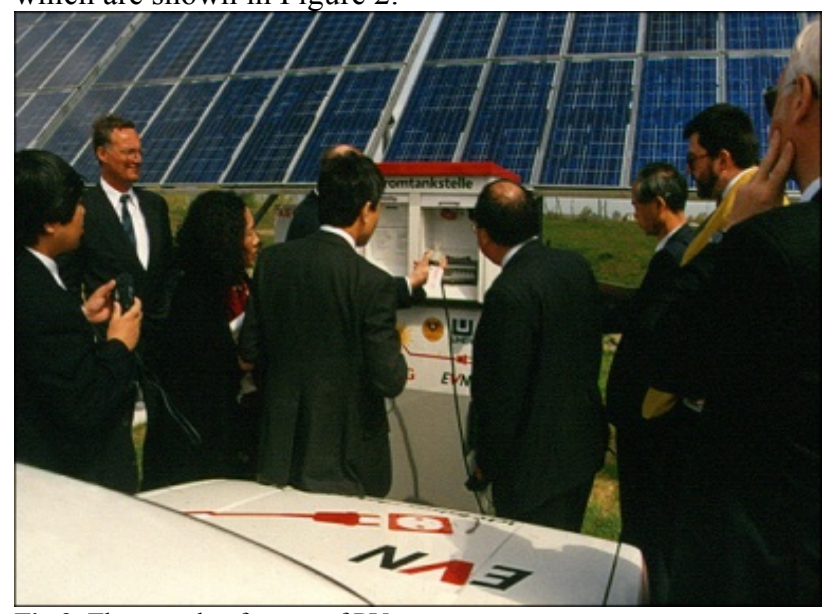

Fig 2. The sample of usage of PV

In general, the use of solar thermal installations in the Kyrgyz Republic can cover the needs of the population in the hot water up to $90 \%$ for $8-9$ months of the year, significantly reduce heating costs up to $50 \%$ during the heating season. There may be a great help in providing electricity to customers located in the low-power remote zone (foresters, shepherds, beekeepers, etc), as well as provide a backup power supply to $30 \%$ of the rural population, providing savings of conventional fuels [3].

In the republic as a very promising is the use of biogas plants (BP). Since its application due to the presence of free access to biomass (animal waste) due to the presence of a significant quantity of farm animals in rural areas $(60 \%)$ are mostly mountainous and foothill regions of the country. The use of biogas plants (BP) provides $30 \%$ of rural residents in the domestic gas to get high fertilizer, which can collect higher yields of agricultural crops by $10-15 \%$. Figure 3 . shows the design of one of the BP for combustible gas.

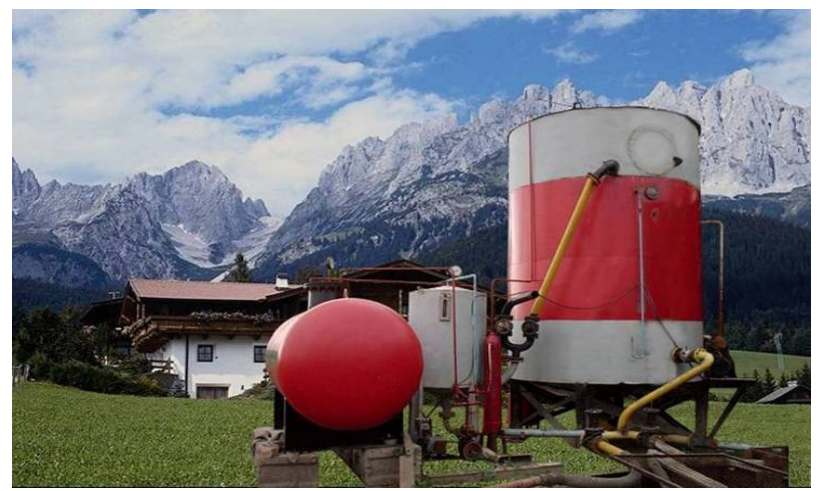

Fig 3. The common view of Biogas Plant

The use of wind energy in the country and can cover from 5 to $7 \%$ of electricity needs in rural areas, to provide additional irrigation of farmland. Very promising is wind power systems (wind turbines) in the foothill and mountain conditions to ensure the autonomous electricity mountain residents and meteorological stations, border posts, and others. Figure 4 . The view of the new class of low-power bi rotor wind power plant. 


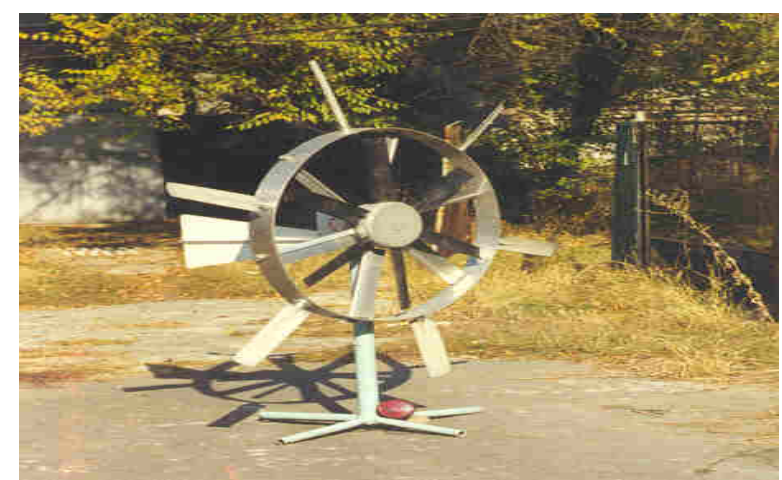

Fig 4. Low-power bi rotor wind power plant

The use of large wind turbine systems is possible in the central regions of the country such as; Shamaldysay, Alay plateau Suusamyr, Barskounskoe valley and other places where there is a constant flow of wind energy.

In the highlands of the country and the presence of many small mountain streams determine the future development of micro hydropower plants. The total hydropower potential of the republic surveyed 172 rivers and streams with flow rates ranging from 0.5 to $50 \mathrm{cu}$. $\mathrm{m} / \mathrm{s}$ over 80 billion kilowatt hours per year, of them is technically acceptable to the development of 5-8 billion kilowatt hours per year. The republic has enough accumulated vast experience in the use of micro hydro power for stand-alone facilities. Figure 5. Micro hydro power plants.
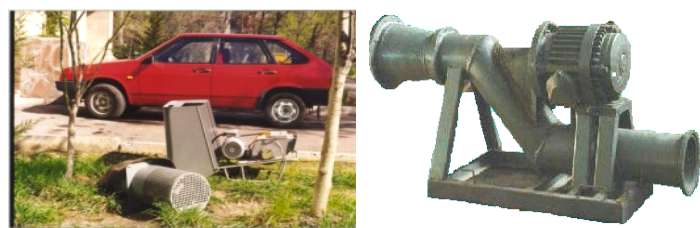

Fig 5. Industry samples of micro hydro power plants (1 kW, $5 \mathrm{~kW})$.
Thus, the use of new innovative renewable energy technologies would greatly solve the issues of electricity consumers are far from centralized energy supply. However, despite of the definitely domestic experience in production of industrial equipment, on its installation and operation, unfortunately the overall development of the renewable energy sector has not been properly developed in Kyrgyz Republic. For that effects the various reasons, such as low public awareness of renewable energy technologies, the lack of State funding for the development of renewable energy sources, lack of adequate human resource capacity, low legal framework, lack of state agencies (Agency for development of RES) is responsible for the development of renewable energy [2].

For a sustainable development of the Kyrgyz Republic it is necessary to reduce the fossil fuel consumption by improving energy efficiency of residential buildings and appliances as well as by introducing renewable energies. This will decrease the stress of rising energy prices on population and public budgets and, thus, even reduce the risk of political instabilities.

For overcome these barriers, it is advisable to create a State Agency for renewable energy (such as the Ministry of Renewable Energy as in India). At the same time government should be involved in raising funds for the implementation of renewable energy projects including investments. There is need for foster human resources policy through training the high and vocational education and training. Government needs to adopt new advanced program to develop renewable energy.

Therefore our main aim to accumulating the experiences by participating in Innovation and Intelligent European Summer School on «PV systems engineering and the other RES» in Patras, Greece during 1-12 July 2012 and constructing the long lasting collaborations with EU scientists on developing the RES in Kyrgyz Republic.

\section{References}

1. A. Dj Obozov, Bishkek, Renewable Energy, (2010).

2. S.K. Turusbekov, Bishkek, International scientific conference "Energy and Energy Efficiency: Status and Challenges "The current status and prospects of renewable energy sources in Kyrgyzstan" (2011).

3. A. Dj. Obozov, Bishkek, Use of Biogas Technology, JICA (2011). 